\title{
COLONIALIDADE E FORMA DA SUBJETIVIDADE MODERNA: A VIOLÊNCIA DA IDENTIFICAÇÃO CULTURAL NA AMÉRICA LATINA
}

- MAURILIO LIMA BOTELHO

Resumo: 0 objetivo do texto é relacionar a descoberta e conquista do continente americano não apenas com a construção da identidade histórica e geográfica europeia, mas também com a estrutura da subjetividade moderna. Como parte desse processo, os pressupostos da superioridade europeia são enfatizados em sua particularidade racial, de gênero e dotados de uma racionalidade que revelam 0 eurocentrismo integrante da relação entre modernidade e colonialidade.

Palavras-chave: modernidade, colonialidade, identidade, racismo, subjetividade.

Introdução

Os vínculos entre cultura e relações de poder ainda são um dos temas controversos na teoria social contemporânea. Acrescentando-se as determinações econômicas a essa relação, a discussão torna-se tão multifacetada quanto os seus interlocutores - cada teórico supõe como básico ou estruturante um conjunto categorial diante de outro, repercutindo as infindáveis controvérsias sobre o que é determinante, se a cultura, o poder ou as relações econômicas. Em que pese toda a essa longa discussão, é possível reconhecer o acúmulo de teses em torno de uma questão singular que pode servir de base para uma reflexão ampla sobre a relação entre Centro e Periferia do capitalismo mundial.

Particularmente interessante para a compreensão da posição da América Latina 
no mercado mundial, os debates sobre modernidade e colonialidade, realizados por intelectuais latino-americanos, podem oferecer uma plataforma para a articulação entre determinações culturais, relações econômicas e estruturas de poder. Sem preocupação com a polarização formal de um aspecto sobre outro, as formulações de Anibal Quijano sobre a colonialidade do poder são um novo capítulo na identificação das relações estruturais responsáveis pela caracterização periférica da América Latina. Superando as limitações categoriais das teorias sobre o subdesenvolvimento ou o formalismo redutor das Teorias da Dependência, Quijano é ao mesmo tempo um herdeiro dessas tradições e o responsável por uma nova abordagem teórica em que a configuração periférica do subcontinente é mediada por complexas relações de identificação racial, formas de produção, hierarquização do poder e estruturas cognitivas.

Apresentando uma teoria em que a decodificação da América Latina é parte integrante de uma crítica da modernidade e da subjetividade moderna, as indicações de Quijano devem ser vistas num contexto mais amplo de reformulação de uma crítica do capitalismo, só possível hoje pelo esgotamento e saída de moda das teorias pós-modernas e também pela já avançada decadência do "materialismo histórico" como cânon teórico. Embora com poucos interessados nessa empreitada, o esforço de dissecação das conexões internas entre forma econômica, dominação social e seletividade cultural, realizado por Quijano ou Enrique Dussel (que também utilizaremos a seguir), poderia ser aproximado e confrontado ao projeto atual de resgate da teoria do valor de Marx e de sua crítica do fetichismo. Singular por encarar as relações mercantis não em uma pureza econômica (embora formal e objetivamente abstratas), mas atravessadas e determinadas por traços culturais e sexuais, essa nova interpretação crítica do capitalismo tem sido levada a cabo por autores como Roswitha Scholz e Robert Kurz (falecido recentemente).

O pressuposto dessa possível aproximação é considerar a periferia não como uma mera extensão territorial e econômica rarefeita do mercado, isto é, margem opaca do Centro capitalista, mas o seu outro, constituído por uma descontinuidade no processo de modernização e por uma cisão em relação à "subjetividade transcendental", um desnível que contém a diferenciação racial, econômica e política como marca da 
socialização cotidiana. Nosso objetivo nas páginas seguintes consiste em apontar os elementos principais dessa interpretação da periferia capitalista, aproveitando abordagens diversas que têm pontos de aproximação e levantando aspectos divergentes sem ignorar a origem diferenciada de cada uma delas. Nossa intenção, contudo, não é realizar uma apresentação sistemática ou comparativa, mas reproduzir os argumentos principais que possam fornecer um fio condutor que enquadre a colonialidade no horizonte opressivo e destrutivo da modernidade. Um confronto mais sistemático e categorial deverá ser feito em outra oportunidade, enfatizando aqui apenas como as diferentes formas de inserção social na maquinaria do mercado (diferentes formas de produzir) estão atreladas à classificação social diversa, isto é, ao gênero e às raças consideradas inferiores do ponto de vista da subjetividade burguesa. Essa seletividade é inseparável da forma como foi construída a racionalidade moderna, em que pese todo o seu floreado discurso sobre a universalidade.

\section{A conquista do Novo Mundo como afirmação da identidade moderna}

A descoberta da América por
Cristovão Colombo, em 1492, deve ser tomada como um dos pontos fundamentais na constituição da identidade moderna. Ao contrário do discurso oficial europeu, que em geral constrói narrativas sobre sua formação identitária de um ponto de vista exclusivamente interno, autônomo, autocentrado, a denominação da própria Europa moderna não pode ser excluída desse evento fundamental que é a "invenção" da América 2. O discurso moderno sobre a identidade europeia só se sustenta em sua autossuficiência recalcando a sua base periférica. A consciência, já nos primeiros anos da construção do império marítimo da Espanha, a partir das viagens de Américo Vespúcio, de que aquelas terras consistiam um Mundus Novus -- não se tratando de parte da China como Colombo imaginou inicialmente -- é momento importante da constituição da identidade da Europa como o Velho Mundo.

Com essa oposição começa a operar um mecanismo de deslizamento semântico que, embora inconsciente, é sistemático. Culturas, grupos sociais e indivíduos são marcados, sedimentando na estrutura social pré-concepções que estão na raiz da identificação excludente, seletividade e extermínio. Concepções que, apesar de prévias para a consciência dos agentes, é o 
produto desse mecanismo de ressignificação terminológica que irá operar durante décadas e séculos na instauração da Idade Moderna. A definição de Europa é o exemplo acabado disto.

Enrique Dussel (2005) enfatizou o papel central desempenhado pelo romantismo alemão na "invenção" da Europa, ou seja, na reelaboração semântica desse termo que passa a representar algo completamente distinto de sua origem na Antiguidade. Enquanto Europa designava mitologicamente a bela filha do rei da Fenícia - uma semita, portanto - a Europa tal como conhecemos hoje está culturalmente associada à herança grecoromana. Isso de modo algum corresponde à sua delimitação geográfica original: para os gregos, a Europa abarcava as terras que eram ocupadas pelos bárbaros. É expressiva essa reviravolta: os europeus são os bárbaros na Antiguidade, aqueles que não sabem pronunciar o idioma grego, aqueles que não sabem se comunicar, os que apenas balbuciam (a raiz latina de bárbaro tem essa conotação). Bárbaros para os helênicos, também não podiam ser comparados aos povos do Sul e do Oriente (África e Ásia de hoje), onde ficavam "culturas mais desenvolvidas, e o gregos clássicos têm clara consciência disso" (DUSSEL, 2005: 41).
Definindo-se a partir da luta contra o mundo muçulmano - o mouro ímpio- e pela dominação colonial no Novo Mundo o selvagem inculto -, a Europa começa a ser criada a partir de uma identificação linear com a cultura latina, helênica e cristã (1492 é tanto o ano da grande descoberta quanto da reconquista de Granada). O mundo árabe, que valorizava, resguardava e reproduzia o conhecimento grego há séculos - enquanto a Igreja Medieval tratava em boa parte como cultura herética —, torna-se a parte bárbara do resto do mundo, embora não seja iletrada como os novos pagãos descobertos na América. $\mathrm{O}$ romantismo alemão, aprofundando e consolidando esquemas identificatórios que começaram com o Renascimento italiano, a descoberta da América e a luta travada contra os muçulmanos, leva ao extremo o processo de elaboração de marcas culturais, capacidades intelectuais e raças - no limite, a Europa é uma criação ariana ${ }^{3}$.

Nesse momento, a Europa constrói um discurso em que se encontra no Centro do mundo, não apenas centro geográfico (que os mapas não cansam de nos mostrar), mas também centro histórico, pois é a primeira vez em que se constitui uma verdadeira história universal. Com as navegações e a formação do mercado 
mundial, a Europa se torna o Centro a partir do qual se interligam a América (suas terras de além mar), a África (futura fornecedora de força de trabalho escrava) e a Ásia (fonte das tão disputadas especiarias). A viagem de Colombo, símbolo máximo do nascimento de um novo mundo, uma nova época, é também o evento inicial do domínio mundial europeu.

Nascia assim o "moderno sistema mundial" (Wallerstein), uma articulação de territórios em diversas partes do mundo através de um sistema de circulação de mercadorias em sua fase inicial ("capitalismo comercial"). Um sistema de bombeamento de riquezas para o Centro que permitiria não apenas uma mudança em sua natureza (o amadurecimento posterior como um "sistema produtor de mercadorias", como capitalismo industrial), mas também a própria consolidação das identidades nacionais europeias (a formação do moderno Estado-Nação).

Em sua primeira viagem a América, contornando diversas ilhas em busca da terra que tinha sido visitada por Marco Polo, Colombo encontrou uma baía em Cuba que lhe fez redigir uma descrição tão pasmada do local, misturando-se aos projetos futuros de ocupação territorial, que demonstram o espírito nascente desse encontro:

E Vossas Altezas ordenarão que uma cidade e fortaleza sejam construídas nestas partes e que estas terras sejam convertidas; e asseguro a Vossas Altezas que me parece que jamais poderá haver sob o sol [terras] superiores em fertilidade, em brandura de frio e calor, em abundância de água boa e sadia (...) terra adentro deve haver grandes povoados e inumeráveis pessoas e coisas de grande lucro; porque aqui, e em tudo mais que descobri e tenho esperança de descobrir antes de voltar à Castela, digo que toda a Cristandande fará negócios com eles, mas, acima de todos, a Espanha, a qual tudo isso deve ficar sujeito. E digo que Vossas Altezas não devem consentir que qualquer estrangeiro comercie ou ponha os pés aqui, exceto a Cristandade Católica, desde que este foi o fim e o começo da empresa, que foi para o engrandecimento e glória da 
religião cristã, nem deve ninguém que não seja um bom cristão vir a estas partes (apud SALE, 1992: 110-111).

Ainda que essas palavras pareçam indicar o contrário, desde o princípio a colonização será marcada pela violência. Os "bons costumes" que serão instaurados daí em diante - a começar pelas primeiras experiências de colonização sob o governo de Colombo —, nada mais são do que a submissão arbitrária às ordens e vontades dos espanhóis, o esforço interminável e duro de servir aos brancos, a violação das mulheres e a obrigação de produzir riquezas- principalmente ouro. As primeiras instituições estabelecidas por Colombo à serviço da Rainha de Castela são o imposto obrigatório de cada indígena na forma de uma determinada quantidade de ouro (para o qual o não cumprimento seria punido com a amputação das mãos) e o sistema de encomienda, proveniente da Espanha, mas agora adaptado como uma forma de cristianização — os espanhóis recebiam um grupo de índios diante dos quais se responsabilizavam a ensinar os bons costumes cristãos. Isto não passava de uma forma pouco velada de escravidão, pois os índios tornavam-se propriedade dos senhores, sendo obrigados a fazer toda a sua vontade, sob o risco de perder a vida.

A identidade da moderna sociedade europeia é forjada a ferro e fogo, marcada em todas as frentes pela violência aberta e sistemática, desde a expulsão dos mouros até a colonização da América. É preciso enfatizar isso porque a subjetividade moderna nasce desse desenrolar da vontade dos conquistadores sobre os povos que deverão ser submetidos, é a imposição de uma vontade soberana que submete tudo à sua frente que permitirá o nascimento da estrutura subjetiva do mundo burguês. A liberdade da vontade, a sua forma abstrata que ignora qualquer obstáculo natural ou social, tal como presente na filosofia moderna burguesa, foi parida pela violência colonial ${ }^{5}$.

A violência colonial atingiu todas as formas possíveis, antecipando e sintetizando os momentos mais sangrentos da modernidade nos séculos seguintes. As atrocidades forjaram a identidade abstrata da modernidade, mas a sua realização não foi em absoluto sempre idêntica. O frei dominicano Bartolomé de Las Casas tornou-se o mais conhecido denunciador do massacre dos espanhóis no Novo Mundo. Sua obra tornou-se um fardo para o nascente Império Espanhol ao apontar com 
detalhes o terror promovido em suas novas terras — suas queixas são contemporâneas das grandes descobertas, tendo ele próprio participado inicialmente da colonização, nos primeiros anos do século XVI, como encomendero na ilha de Hispaniola (atual ilha de São Domingos) ${ }^{6}$. Biógrafo de Cristovão Colombo, escreveu vários livros que descreviam minuciosamente a destruição das sociedades nativas, o que causou grandes debates públicos e processos que culminaram com a proibição legal da escravidão indígena (posterior à morte de Las Casas).

Na obra mais famosa de Bartolomé de Las Casas sobre o assunto, Brevíssima Relação da Destruição das Índias, a violência colonial apareceatravés de uma infinidade de métodos. Colonos espanhóis cortavam índios ao meio apenas para averiguar se suas espadas estavam bem afiadas; decapitações e enforcamentos como forma de punição eram comuns; fogueiras eram acesas para queimar líderes astecas ou maias; cães treinados para, em matilha, esquartejar crianças, jovens ou mesmo adultos; bebês eram alimentos para os cães; orelhas eram cortadas daqueles que se recusavam a servir aos espanhóis; mãos amputadas por punhais para que os demais índios aprendessem com o exemplo; por vingança, mulheres e crianças eram lançadas em valas forradas com estacas afiadas armadilhas montadas pelos indígenas em guerra contra espanhóis; estupros coletivos eram comuns assim como aldeias e vilas queimadas para expulsar os índios das terras de interesse colonial.

Toda essa trágica história de genocídio tinha por objetivo forçar os índios ao trabalho, obrigá-los à exploração nas minas (onde morreriam pelo esforço excessivo ou pela má alimentação) e às lavouras que cultivavam para alimentar os brancos ou para artigos de exportação. Com a ocupação iniciada, também eram obrigados à construção de fortes, igrejas e vilas inteiras para os brancos, num processo exaustivo e com quase nenhum descanso. Os ameríndios ainda trabalhavam como escravos em minas de esmeraldas ou mergulhavam por longos minutos à procura de pérolas nos mares do Caribe, onde morriam afogados, envenenados e com irreversíveis seqüelas da falta de oxigênio.

(...) os cristãos com seus cavalos, espadas e lanças começaram a fazer matanças e crueldades estranhas. Entravam nos povoados, não poupavam crianças nem velhos, mulheres grávidas e parturientes, abrindo-lhes o 
ventre e fazendo-as em pedaços, como se fossem cordeiros. Faziam aposta sobre quem, de um só golpe, abria um homem ao meio, lhe cortava a cabeça ou abria as entranhas. Tomavam os bebês dos seios de suas mães, pelas pernas e batiam com suas cabeças nas rochas. (...) Outros enfiavam a espada nas mães junto com todos quantos diante deles falavam. Faziam forcas largas, de modo que quase os pés tocam na terra, e de treze em treze, em honra e reverência ao Nosso Redentor e dos doze apóstolos, colocavam lenha e os queimavam vivos. Outros, atavam ou envolviam todo o corpo em palha seca, tocando-lhes fogos e queimando-os vivos (LAS CASAS, 1986: 24). ${ }^{7}$

Tudo isso com um propósito muito claro, que não era de modo algum escondido ou recusado: a busca insaciável de riqueza monetária, ouro principalmente. "A causa pela qual os cristãos têm matado tantos e destruído tão infinito número de almas não tem outra finalidade que não o ouro e encher-se de riquezas", diz Las
Casas (1986: 23), sem meias palavras.

Exprimindo o choque entre motivos sociais tão diversos, a sua narração, em outro momento, resvala na definição do princípio moderno de socialização. Las Casas (1986: 30) conta que um cacique da ilha de Hispaniola entregou um cofre cheio de ouro e jóias para os espanhóis, que o haviam aprisionado, declarando em seguida: "Eis aqui o Deus dos espanhóis".

É verdade que em conjunto com esse vil objetivo, a colonização poderia ser contada também por uma série de outros motivos, como a busca por novas terras, a tentativa de criar um novo lar (principalmente para os degredados e os fugitivos da Santa Inquisição), a ampliação da glória dos senhores espanhóis ou a ampliação da cristandade, mas tudo não passava - como disse com precisão Kirkpatrick Sale (1992: 248) — de uma "camuflagem auxiliar", uma legitimação para a busca desenfreada por ganhos mercantis.

O que impressiona é que essa pulsão tão violenta, tão clara, evidente e reconhecida pelos próprios atores envolvidos - Sale (1992: 248) cita vários cronistas da época que não se cansavam de enfatizar o "desejo cobiçoso de ouro" tenha sido aos poucos arrefecida na memória coletiva e a história seja 
sistematicamente contada em livros didáticos, em biografias apologéticas ou nos anais oficiais comemorativos como a história de grandes conquistadores, espíritos aventureiros, figuras heróicas que estavam tornando o mundo maior (ou menor), unindo civilizações e culturas. $\mathrm{O}$ interesse mercantil, evidentemente, não é recalcado o próprio acidente histórico, verdadeiro ou não, de terem esbarrado num continente em busca das Índias e suas especiarias não o deixa esquecer. Contudo, a distância histórica parece ter afastado e absolvido os "excessos" cometidos pelos brancos em contato como o Novo Mundo, como se fossem próprios aos limites daquele horizonte histórico, "homens de sua época". Isso ainda é mais absurdo pelo fato de que os séculos seguintes presenciaram a exaustão os mesmos processos: iniciado pelos espanhóis, o extermínio direto (pela violência) e indireto (através de doenças e epidemias) dos índios seria aprimorado por portugueses, ingleses, franceses, holandeses etc. E seriam repetidos também com os negros. ${ }^{8}$ Por exemplo, o próprio Bartolomé de Las Casas (1986: 42-44) descreve os navios que levavam indígenas escravizados para serem comercializados em outras terras ou ilhas, um ensaio para o posterior tráfico de escravos negros no Atlântico, pois as mortes por doenças, torturas e o despejo de "parte da carga" no mar eram já comuns. Assim, o "evento" que é a descoberta da América e sua violenta colonização não é um sombrio desvio na história da modernidade, mas a demonstração de suas condições mais elementares, seu ponto de partida e sua natureza mais evidente, reafirmada de modo insuportável posteriormente. Como deixaria evidente Braudel, "a América foi 'obra' da Europa, a façanha através da qual a Europa revelou mais autenticamente sua própria natureza" (apud SALE, 1992: 252).

Por isso se justifica esse resgate histórico da colonização da América, sua invenção, conquista e encobrimento - para usarmos três das "figuras" elencadas por Enrique Dussel (1992) para discutir a construção da modernidade. Pois se trata evidentemente de um encobrimento da diferença e da alteridade originais, ${ }^{9}$ mas também um empalidecimento histórico de toda a violência cometida contra aqueles que foram conquistados. Além disso, como examinaremos em seguida, ocorreu também a invenção de novas identidades para esses povos, sintetizando uma diferença adjudicada. Tudo isso resultando de uma conquista que foi mais precisamente uma guerra, um processo militar, uma violência 
bélica da modernidade nascente que precisava afirmar-se frente a esse novo horizonte histórico e geográfico:

\begin{abstract}
A 'Conquista' é um processo militar, prático, violento que inclui dialeticamente o Outro como o Mesmo. O Outro, em sua distinção, é negado como Outro e é obrigado, subsumido, alienado para incorporarse à Totalidade dominadora como coisa, como instrumento, como oprimido, como 'encomendado', como 'assalariado' (nas futuras fazendas), ou como africano escravo (nos engenhos de açúcar ou outros produtos tropicais (DUSSEL, 1992: 41-42).
\end{abstract}

Também esse caráter beligerante não deixava de ser da consciência clara de todos os participantes, afinal, através das "guerras justas" os indígenas podiam ser legalmente escravizados, expediente inclusive utilizado pelos próprios dominicanos da Guatemala. Ali, onde em 1536 Las Casas havia iniciado o processo de "dominação pacífica" e "cristianização", anos depois (1558) os padres entraram em guerra com os nativos depois de fracassar sua empreitada espiritual. ${ }^{10}$

Aliás, o que revela bem o estado de espírito da época - ou melhor, a formação do Espírito moderno -, é exatamente o fato de que até os defensores dos nativos, dos quais Las Casas foi o mais radical de todos, compartilhavam de pré-concepções ou desenvolveram caracterizações, no trato com o índio, que acabaram por tomá-lo como inferior e submetê-lo ao aprendizado civilizado. A construção da identidade europeia passava necessariamente pela pressuposição da inferioridade indígena ao apreendê-lo como parte desse opressivo mundo natural das florestas fechadas, rios caudalosos e impetuosas tempestades, mesmo que tivesse a intenção de incorporálo - uma incorporação que passa pela distinção, pela discriminação.

Para Bartolomé de Las Casas (1986: 22), o elogio dos índios, por serem criaturas "muito pacientes", "muito humildes", "muito pacíficas e serenas", passa também pela sua particularização como "muito simples", "sem maldade" e "obedientes", que "muito delicadas e fracas e ternas em sua compleição, (...) não suportam trabalhos; morrendo logo de qualquer enfermidade", "gente paupérrima", por isso "são muito aptos a receber nossa santa Fé 
Católica e serem dotados de bons e virtuosos costumes" ${ }^{11}$ Os relatos do frei são interessantes exatamente por demarcar essa tentativa de salvar a alma desses povos tão selvagens que sequer conheciam a vergonha ou o pecado: muitos padres batizavam os nativos nos últimos minutos de sua respiração, enquanto esvaiam-se em sangue presos em troncos, amarrados em fogueiras com os seus pés já queimando ou quando murmuravam suas últimas palavras em línguas desconhecidas para os brancos. A diferença entre os conquistadores genocidas e os padres catequizadores não é de natureza, mas de método: ambos partiam do mesmo pressuposto da superioridade branca europeia, empenhados na conquista material ou espiritual. E não é casual que assim eles tenham sido vistos pelos nativos. ${ }^{12}$

Também quando há uma possibilidade de comparação, Las Casas (1986: 37) utiliza o turco (muçulmano) como modelo de crueldade, "rebaixando" os espanhóis para a sua condição ao dizer que "as invasões" realizadas pelos cristãos espanhóis "são muito piores do que as que faz o turco para destruir a Igreja Cristã". E, se a discriminação ainda não é evidente, o próprio Las Casas teria sugerido o uso de negros para trabalhar como escravos no lugar dos índios, permitindo assim o trabalho de cristianização - sempre partindo do ponto de vista de que o indígena não rejeita a fé cristã como os judeus e muçulmanos (mouros), mas apenas a desconhece pelo seu estado natural.

De um ponto de vista retrospectivo, portanto, é compreensível que o resultado tenha sido o arrefecimento de toda a destruição praticada pelos colonizadores, lembrada mas não devidamente compreendida e dimensionada em toda sua selvageria. Se até os mais radicais defensores dos nativos estavam envolvidos numa estrutura de pensamento que começava a operar a classificação, seleção e discriminação de uma infinidade de indivíduos, grupos sociais e culturas, então para as gerações seguintes toda a destruição poderia ser justificada, se não econômica, pelo menos espiritualmente pelo trabalho de civilização. Tratava-se de um momento de construção de um aparato perceptivo, uma forma de pensar, uma subjetividade transcendental baseada na diferenciação e seleção, cuja base era a identidade europeia em formação - o ambiente cognitivo próprio ao racismo. Michel de Montaigne (2013: 60), por exemplo, em seus famosos Ensaios, chega até a discorrer sobre a violência e destruição levada a cabo por "certos espanhóis", que arrasaram cidades 
inteiras até o chão, exterminaram nações, passaram milhões de pessoas pelo fio das espadas, viraram "de cabeça para baixo" a "parte mais rica e mais bonita do mundo", simplesmente para "tráfico de pérolas e de pimenta". Mas tudo no fim se torna uma mera reclamação diante da oportunidade perdida de tê-los ensinado a ser civilizados, da incapacidade de ter eliminado "tudo de rude e selvagem entre eles", da falta de interesse em "propagar as boas sementes" ou "as virtudes Gregas e Romanas":

Que indenização seria para eles, que benefício geral para o mundo inteiro, se nossos primeiros exemplos e comportamentos nessas regiões tivessem cativado essas pessoas à admiração e imitação da virtude e gerado entre eles e nós uma sociedade fraternal e inteligência? Como deve ter sido fácil obter vantagem sobre almas tão inocentes e tão ansiosas de aprender, na maior parte das vezes abandonando inclinações antes naturalmente tão boas? Muito pelo contrário, pois o que fizemos foi tirar proveito da ignorância e da inexperiência

deles, induzindo-os com a maior facilidade à deslealdade, luxo, avareza e a todas as formas de desumanidade e crueldade, pelo padrão e exemplo de nossos costumes. Quem alguma vez elevou o valor da mercadoria a preço tão alto? (MONTAIGNE, 2013: 60).

O moralismo tacanho baseia-se numa alternativa histórica que se mostra falsa logo que notamos as pré-concepções de Montaigne (2013: 59): as presumidas diferenças dos índios os fariam na verdade objetos a serem cultivados pelos europeus, para que pudessem ser incorporados e aprendessem o "abecedário" - pois suas tribos viviam em um mundo novo "bisonho e infantil (...); estava até então completamente nu no colo da mãe e vivia apenas do que ela lhe dava".

Esse processo seria coroado, evidentemente, com a sistematização da forma mesma da subjetividade moderna - as filosofias que construíram a teoria sobre o Sujeito. Com os grandes sistemas filosóficos foi solidificada a forma do Sujeito, branco e masculino, e justificadas as atrocidades cometidas no caminho até a sua formação. Com isso fica fácil entender que, com o Se 
em Montaigne já ficava evidente a concepção comum de menoridade dos índios, portanto a necessária condução ou governo pelos brancos, no Iluminismo isso será levado ao extremo. Como se sabe, na clássica definição kantiana, o Iluminismo é concebido como a "saída do homem da sua menoridade de que ele próprio é culpado" (KANT, 1985: 100). Desde o início da conquista da América, os índios são submetidos em função dessa culpa por sua inferioridade. Nas palavras de Juan Ginés de Sepúlveda, um filósofo que debateu exaustivamente com Las Casas sobre a escravidão indígena, os índios são "bárbaros, simples, iletrados e em educação, bestas totalmente incapazes de aprender nada que não sejam habilidades mecânicas, cheios de vício, cruéis e de tal índole que é aconselhável que sejam governados por outros" (apud WALLERSTEIN, 2007: 19).

Também em Hegel a visão sobre a América é carregada de preconceitos, chegando ao ponto de o grande filósofo da história eliminar todo esse continente do caminho do Espírito. Em, sua Filosofia da História, ele apresenta a história universal num caminho que vai do Oriente ao Ocidente, culminando, portanto, na Europa, que "é absolutamente o fim da história universal, enquanto que a Ásia é o seu começo" (HEGEL, 1971: 126). Continua suas asseverações sobre o caminho histórico percorrido pelo Espírito apontando que há três continentes no mundo: Europa, Ásia e África, o que cabe ao Mediterrâneo o papel de centro geográfico e histórico do mundo: As três partes em que se divide o Velho Mundo guardam entre si uma relação essencial e constituem uma totalidade (...). O Mar Mediterrâneo é, portanto, o meio de união destes três continentes, assim como é o centro da história universal (...). Com isto, dito mar é o coração do Velho Mundo, já que o condiciona e lhe dá vida. Sem este mar não poderia conceber-se a história universal; seria como a antiga Roma ou como Atenas sem o fórum, para onde tudo afluía (HEGEL, 1971: 111).

Essa visão do mundo em três continentes é uma herança medieval que Hegel obviamente não mantém por desconhecimento do feito de Colombo, mas simplesmente porque é um padrão que se ajusta bem ao seu sistema filosófico. Por meio dele transforma os asiáticos e africanos na forma inconsciente da razão, enfatizando a herança grega e romana para a realização do Espírito na Europa. Numa passagem longa, mas importante para compreender a imagem que a Europa construiu de si, Hegel define os "modernos" como livres: 
O homem é, por exemplo, pensante, e então pensa o seu pensamento; deste modo, o objeto do pensamento é o próprio pensamento, a racionalidade produz $\mathrm{O}$ racional, a razão é o seu próprio objeto. $\mathrm{O}$ fato que o pensar possa degradar-se até o irracional é uma consideração ulterior que não vem aqui ao caso. Se à primeira vista parece que o homem racional em si não tenha progredido para se ter tornado racional por si, visto que só se manteve o em si, a diferença não deixa de ser imensa: não se tira a limpo nenhum novo conteúdo, e apesar disso esta forma do ser por si constitui uma diferença enorme. Sobre esta diferença se funda o complexo das diferenças dos desenvolvimentos da história do mundo. Só assim se explica como, sendo todos os homens racionais por natureza, e sendo a explicação formal desta racionalidade o serem livres, tivesse havido e haja ainda em muitos povos um regime de escravidão, e que os povos se tenham contentado com tal regime. A diferença entre os povos africanos e asiáticos, por um lado, e os gregos e romanos e modernos, por outro, reside precisamente no fato de que estes são livres e o são por $\mathrm{si}_{\text {; }}$ ao passo que aqueles o são sem saberem que o são, isto é, sem existirem como livres. Nisto consiste a imensa diferença das suas condições. Todo o conhecimento e cultura, a ciência e a própria ação não visam a outro escopo senão a exprimir de si o que é em si, e deste modo a se converter em objeto para si mesmo (HEGEL, 1974: 341-3422).

Os juízos hegelianos sobre a África são assustadoramente racistas, todos envelopados filosoficamente ${ }^{13}$. Mas e os nativos americanos? Hegel parece compartilhar de uma profunda ignorância em relação às sociedades nativas do Novo Mundo, mas não se incomoda com isso, pois transforma o

extermínio daqueles povos numa mera dissipação diante da grandiosidade do 
Espírito, como fica evidente nessas palavras:

Da América e de sua cultura, especialmente no que se refere ao México e Peru, é certo que possuímos informações, mas nos dizem precisamente que essa cultura tem um caráter do todo natural, destinado a extinguirse tão logo o Espírito dela se aproxima. A América tem demonstrado sempre fraqueza tanto física quanto espiritualmente. Desde que os europeus desembarcaram na América, os indígenas têm decaído, pouco a pouco, diante do sopro da atividade europeia, e com estes não poderia mesclar-se os aborígenes, por isso foram deslocados (...). A inferioridade destes indivíduos em todo os sentidos, sobretudo na estatura, pode ser julgada por completo (HEGEL, 1971: 105)

Não é por acaso que o resultado de toda essa elevada justificação filosófica, que consegue abreviar a sangrenta destruição das culturas americanas num "sopro", seja o de colocar o "império germânico" como o ponto culminante de um caminho que sai da infância no "império oriental", passando pelo "império grego" e o "império romano" (HEGEL, 1997: 312-217). ${ }^{14}$

A postura seletiva do pensamento moderno fica evidente - a razão, presumida como exclusividade europeia (ou seja, dos modernos), coloca-se acima de todos, orientais, africanos ou indígenas americanos. Como um instrumento particular dos europeus, a racionalidade é meio para a consciência e conquista da liberdade. ${ }^{15}$

No entanto, foi Immanuel Kant que passou a história como o mais importante teórico da subjetividade moderna - sua filosofia consistiu basicamente em definir de modo puro a forma mesma da Razão. Sua obra foi considerada a elaboração teóricofilosófica mais acabada das categorias básicas da modernidade burguesa, isto é, sua reflexão voltou-se à definição da liberdade, da vontade e até mesmo da igualdade e universalidade. Tanto para as gerações seguintes, quanto em sua própria avaliação, seu esforço de esmiuçar os fundamentos transcendentais da Razão e do Sujeito é a versão filosófica da Revolução Francesa. Contudo, apesar de todo esse referencial pretensamente emancipatório, 
Kant sintetizou como ninguém as contradições da racionalidade classificatória, seletiva e excludente.

A começar pela sua misoginia teórica - segundo Kant, a esfera do "elevado" ou do "sublime" não é própria à mulher, pois esta se circunscreve ao "belo", isto é, ao sensível, carinhoso e delicado. O texto que passa em exame essa diferença, Observações sobre o sentimento do belo e do sublime: ensaio de estética moral, é cuidadosamente redigido para ser elogioso ao "belo sexo", mas o resultado é a síntese de todos os preconceitos típicos patriarcais. Kant enfatiza com cuidado a comparação entre homem e mulher, pois não se tratam de "pessoas do mesmo gênero". Em seguida, realiza um tratamento superior diante dos negros, que também são incapazes de alcançar o sublime ou se dedicar a uma compreensão profunda das coisas. Aqui a discriminação é estabelecida pela definição da cor:

Os negros da África carecem por natureza de uma sensibilidade que se eleva por cima do insignificante. $\mathrm{O}$ senhor Hume desafia qualquer um a apresentar um exemplo em que o negro tenha mostrado talento, afirma que entre as centenas de milhares de negros transportados para terras estranhas, e ainda que muitos deles tenham obtido a liberdade, não se encontrou um somente que tenha imaginado algo grandioso como na arte, na ciência ou em qualquer outra qualidade honrável, enquanto entre os brancos é comum o caso daqueles que suas condições se levantam de um estado humilde e conquistam uma reputação vantajosa. Tão essencial é a diferença entre estas duas raças humanas, apresentando-se tão evidente nas faculdades espirituais quanto na cor (KANT: 2013).

Por fim, pode-se ver o trato distintivo que Kant oferece aos índios: começa pelo elogio de que não há nenhum povo que mostre caráter mais sublime do que os selvagens norte-americanos. Já os canadenses são muito orgulhosos e fazem da liberdade seu maior valor a ser defendido, resistindo a qualquer submissão. Esse apego desmedido e elevado à liberdade, contudo, não é exatamente um elemento positivo 
para ele, o mais ferrenho defensor do autocontrole baseado "nas leis morais" - em função desse espírito indomado, são incapazes do generoso perdão de uma ofensa, sendo a "a bravura o maior mérito do selvagem, e a vingança a sua mais doce voluptuosidade". Kant (2013) termina por desprezar os demais indígenas do continente americano, pois "mostram poucos sinais de um caráter apto pelos sentimentos delicados e a característica de tais raças é uma extraordinária insensibilidade".

Todas essas formulações não são detalhes menores na obra do maior filósofo da modernidade - são na verdade a conclusão lógica da forma abstrata que ele desvelou na subjetividade transcendental. Apenas com a recusa de qualquer critério que não seja o da racionalidade pura e simples é que pode o sujeito operar com liberdade, consciência e fazer valer a sua vontade. Para operar no elevado mundo das categorias puras, o sujeito precisa recalcar todos os elementos concretos e sensíveis, o que significa tomá-los de antemão como inferiores, diminuí-los a objetos de sua vontade e de sua ação. Isso implica em delimitar num campo oposto e rebaixado todos os indivíduos que, "diferentes", são identificados por seus caracteres naturais imediatamente perceptíveis - a cor e o sexo. Assim, revela-se o caráter seletivo e excludente da racionalidade moderna, que o Iluminismo transformou na mais alta característica do homem europeu:

O Iluminismo desde sempre se fundamentou em mecanismos de exclusão e, ao fim e ao cabo, apenas o branco masculino se qualifica para a esfera do elevado. Esta exclusão misantrópica parece ser estruturalmente necessária, porque a abstração operada pela consciência razoável do homem tem sempre de fazer, e quer sempre fazer referência ao seu produto colateral que é o oposto irracional. É também assim que Kant "acrescenta" ao seu entendimento, que pensa de um modo cientificamente abstrato e profundo, o belo entendimento, sensível e de bom coração. $\mathrm{O}$ mais tardar aqui se torna evidente que a gloriosa razão de Kant não é sinônimo de algum diálogo que, enfim, também não deixa de ser necessária até certo ponto, entre humanos 
que querem argumentar de um modo razoável. Antes, a racionalidade iluminista é, na sua estrutura fundamental, tão inconsciente quanto é bárbara, porque associa a sua lógica à raça e ao sexo e a constituição de uma esfera abstrata do elevado sempre vai de mãos dadas com o domínio sobre algo de identificável e rebaixado. A desmedida

autossobrestimação do masculinamente elevado, no entanto, apenas pode afirmarse despromovendo outros à natureza. $\mathrm{O}$ oposto como produto colateral, que a razão quer agraciar com um tratamento hierárquico, é projetado sobre um grupo socialmente identificável. A razão masculina fica com o reino das formas puras e dos princípios abstratos para si, visto que Kant definitivamente não acredita em que "pretos" ou "o belo sexo seja[m] capazes dos princípios" (WEDEL, 2010).

É inacreditável que o Iluminismo ainda hoje seja tomado como o mais avançado movimento intelectual universalista, que teria colocado o Homem acima de tudo, independente de raça, sexo, religião etc. De forma não-velada, sua inclinação para a diferenciação é baseada em critérios que são recentes na história, específicos da modernidade: o furor desenfreado de assimilar a mulher à beleza natural, os índios à infância selvagem e os negros à inferioridade bárbara é um resultado da própria história de constituição da identidade europeia, para o qual a invenção da América teve um papel fundamental. Os elementos naturais e a própria humanidade tomada em estado natural ou de barbárie passa a ser sistematicamente enquadrada na filosofia kantiana, sendo rebaixados a objetos para o sujeito masculino e branco. ${ }^{16}$

A colonização não é apenas um movimento objetivo violento de construção da ordem burguesa através dos recursos monetários (ouro e prata), recursos naturais (madeira, tabaco, açúcar, café etc.) e força de trabalho (negros e indígenas) -- todos esses "fatores da produção" arrancados, expropriados e explorados aos limites do imaginável. A colonização é também um processo subjetivo de construção da consciência burguesa, que cria a representação de sua própria condição 
numa ordem social e natural, ao mesmo tempo que projeta sobre o Outro uma imagem inferiorizada nesta ordem. Todo esse movimento de constituição da consciência moderna é um processo subjetivo, mas não num sentido particularizado - $\quad$ embora sua individualização seja a própria forma de existência do sujeito burguês iludido de uma autoconsciência, livre e com vontade plena. A colonização é a própria origem social da subjetividade transcendental, a forma moderna de relacionamento subjetivo-simbólico, matriz formal da consciência burguesa.

\section{Forma da produção e raça na definição colonial}

O processo de constituição da seletiva subjetividade transcendental não é algo meramente mental ou do plano exclusivo da compreensão simbólica, pois foi atravessado desde o início por relações objetivas que também se caracterizaram pela diferenciação e dissociação. A universalidade do domínio burguês - que pouco a pouco a vai sendo construída até ser estabelecida de vez com a industrialização na Europa - está desde o princípio de sua formação marcada por zonas negativas, esferas de exclusão. A pretensa universalidade do sujeito da modernidade é acompanhada pela delimitação e classificação de modos de produzir diferenciado segundo grupos e indivíduos.

A descoberta da América é o passo inicial na construção dessa relação contraditória entre universalismo-exclusão, pois a "conquista" dos territórios "virgens" é a ampliação do domínio ocidental e constituição de um sistema que agora se tornava efetivamente mundial - menos de 50 anos depois da viagem de Colombo, todas as grandes massas significativas de terras serão mapeadas. Essa ampliação do território sob domínio europeu é atravessado por paradoxos, cuja expressão mais evidente é o estatuto do índio, reconhecido como livre do pecado ou da vergonha mas que precisa ser civilizado exatamente pela sua inferioridade natural. Nessa diferenciação do índio frente ao europeu, ocorre uma abstração das particularidades culturais específicas das várias tribos e sociedades, para que todas sejam reduzidas e amalgamadas nesse termo vazio e geograficamente equivocado de índio. Uma infinidade de centenas de etnias diversas são apagadas do conhecimento 
ocidental e simplesmente convertidas em indígenas ou, o que revela ainda mais o ponto de vista da dominação colonial, "povos pré-colombianos".

O passo seguinte no processo de colonização foi a utilização em massa da força de trabalho escrava oriunda da África, mercadoria essencial ao comércio metropolitano. Assim como ocorreu com os nativos do novo continente, as tribos africanas atacadas para fornecer espécimes para o "mercado de carne negra" foram dissolvidas na denominação de negro.

Milhares de culturas foram transformadas na mais infame das mercadorias e simplesmente designadas como africanos ou mouros - também esta última uma denominação histórica e geográfica equivocada, mas explicável pelo conflito que é parte do nascimento da identidade europeia. ${ }^{17}$ Por fim, em cerca de 20 anos, no final do século XIX, pelo menos 10 mil tribos africanas foram convertidas em 40 Estados, 36 sob domínio colonial europeu (FERGUSON, 2010: 239).

$\mathrm{Na}$ composição do mercado de escravos se consolida a diferenciação sistemática desses grupos frente ao europeu. Um dos mais complexos e opressivos mecanismos de sedimentação ideológica entra em operação para justificar a escravidão e utilização maciça do negro como força de trabalho cativa. O debate teórico e historiográfico atravessou gerações, mas devemos ao clássico livro de Eric Willians, Capitalismo e escravidão, a melhor explicação para a formação dessa instituição social essencial ao nascimento do capitalismo.

A questão se refere principalmente ao motivo de os colonos europeus terem optado, a partir de determinado momento, pelo uso da força de trabalho negra no lugar da indígena. Embora os nativos americanos nunca tenham se livrado da intensa exploração - e muito menos do cativeiro , com a proibição oficial da sua escravidão o grande mercado transatlântico da população africana foi aberto.

Criticando todas as concepções que postulam uma habilidade inata do negro para o trabalho duro - enquanto os indígenas seriam indolentes e frágeis Eric Williams demonstra que nos primórdios da colonização americana foram utilizados indiscriminadamente trabalhadores cativos índios, negros e até mesmo brancos. ${ }^{18}$ A questão não está em uma pretensa aptidão natural ou compleição física - "impressão" que é ela mesma o resultado dos preconceitos e da justificação posterior da opção pelos negros. A 
determinação do negro como escravo foi uma escolha baseada fundamentalmente no mercado: "A escravidão não nasceu do racismo: ao contrário, o racismo foi uma conseqüência da escravidão. $\mathrm{O}$ trabalho não-livre no Novo Mundo era moreno, branco, negro e amarelo; católico, protestante e pagão" (WILLIAMS, 1975: 12).

$\mathrm{O}$ que ficaria posteriormente muito evidente é que somente com o transporte da força de trabalho entre continentes poderiam a metrópole faturar. Se os índios fossem utilizados massivamente como escravos, o comércio de cativos seria interno às colônias - e já não poderiam ser utilizados massivamente porque foram exterminados, muitas ilhas da América Central apresentando inclusive escassez de mão-de-obra. Com a proibição de captura de índios para tal fim - embora ainda algumas "guerras justas" fossem realizadas com esse objetivo - a alternativa de trazer escravos da África tornava-se parte do monopólio metropolitano, com o que os navios europeus passam a realizar aquele caminho conhecido e lucrativo do "comércio triangular", conectando três continentes e circulando a cada momento com uma mercadoria diferente em seus porões.
A concepção de raça - esse conceito que se tornou tão importante e tão onipresente, mas que é vazio de qualquer sentido biológico preciso - nasce como justificação a posteriori para a escravidão negra, ressaltando traços físicos, aptidões naturais e diferença de força que não passam de uma invenção.

É profunda, insistente e virtualmente universal a admissão de que 'raça' é um fenômeno da biologia humana que tem implicações necessárias na história natural da espécie e, em conseqüência, na história das relações de poder entre os indivíduos. Isso radica, sem dúvida, na excepcional eficácia deste moderno instrumento de dominação social. Não obstante, trata-se de um pobre constructo ideológico que não tem, literalmente, nada que ver com a estrutura biológica da espécie humana, mas tem tudo a ver, em troca, com a história das relações de poder no capitalismo mundial,colonial/moderno, eurocentrado (QUIJANO, 
1999: 186).

$\mathrm{O}$ processo seguinte seria sistematizar filosoficamente as concepções de superioridade europeia - o homem branco é a base para a formulação abstrata da racionalidade. Apesar de suas formas transcendentais a priori, a figura do sujeito foi na verdade concebida por meio do recalque da sensibilidade e da concretude, pois só assim pode afirmar-se hierarquicamente sobre um mundo natural, feminino e bárbaro abaixo dele.

Depois de grandes filósofos comprovando por meio da mais elevada razão que os povos não-europeus são desprovidos da mesma capacidade intelectiva que o homem branco, restaria à biologia e antropologia comprovar cientificamente as diferenças raciais, construindo assim um tosco amálgama entre história e biologia, consolidando a formulação das "identidades sociais e geoculturais" (Quijano) que estavam em gestação desde a descoberta de Colombo.

Três séculos depois do início da conquista da América, já com vários territórios tendo obtido sua independência, pelo menos formalmente, os caracteres constitutivos da colonização passam a compor de modo negativo não apenas a subjetividade burguesa como são agora conscientemente retrabalhados como formas científicas de classificação e diferenciação da humanidade. E a mais evidente força da colonialidade, isto é, de um modo especificamente moderno de hierarquização social e divisão de poder que está baseado numa distinção racial e sexual. Mas não apenas isso, pois a colonialidade é também um modo especificamente moderno de construção da subjetividade e de relações intersubjetivas baseadas na diferenciação e exclusão.

Esse resultado da história do poder colonial teve duas implicações decisivas. A primeira é óbvia: todos aqueles povos foram despojados de suas próprias e singulares identidades históricas. A segunda é, talvez, menos óbvia, mas não é menos decisiva: sua nova identidade racial, colonial e negativa, implicava o despojo de seu lugar na história da produção cultural da humanidade. Daí em diante não seriam nada mais que raças inferiores, capazes 
somente de produzir culturas

inferiores. Implicava também sua relocalização no novo tempo histórico constituído com a América primeiro e com a Europa depois: desse momento em diante passaram a ser o passado. Em outras palavras, o padrão de poder baseado na colonialidade implicava também um padrão cognitivo, uma nova perspectiva de conhecimento dentro da qual o não-europeu era o passado e desse modo inferior, sempre primitivo (QUIJANO, 2000: 221).

A grande contribuição de Anibal Quijano é exatamente estabelecer uma relação, até então não percebida teórica e sistematicamente, mas agora quase óbvia, entre os critérios de classificação racial e as formas de inserção no sistema mundial capitalista. Se o trabalho livre é a forma moderna mais acabada de relacionamento social, então o resultado mais profundo da colonialidade é a determinação de que formas não-assalariadas de produção devam ser adjudicas aos grupos inferiores na distinção racial. O critério racial anda a par com a forma de produzir.
Assim como a determinação da escravidão negra foi o resultado de um modo específico de inserção das sociedades africanas no comércio mundial - como objetos desse comércio -, em toda a América os diversos grupos racialmente discriminados são incluídos no moderno sistema mundial de modo específico, correspondente à sua identidade inferiorizada. É um conjunto categorial novo, não se tratando de herança de nenhuma sociedade pretérita - seja ela a escravidão antiga ou servidão feudal —, mas uma articulação original entre o nascente mundo do capital e formas de produção de mercadorias consideradas "nãoassalariadas":

O fato é que já desde o começo da América, os futuros europeus associaram o trabalho não pago ou nãoassalariado com as raças dominadas, porque eram raças inferiores. $\mathrm{O}$ vasto genocídio dos índios nas primeiras décadas da colonização não foi causado principalmente pela violência da conquista, nem pelas enfermidades que os conquistadores trouxeram em seu corpo, mas porque tais 
índios foram usados como mão de obra descartável, forçados a trabalhar até morrer. A eliminação dessa prática colonial não termina, de fato, senão com a derrota dos encomendeiros, em meados do século XVI. A reorganização política do colonialismo ibérico que se seguiu implicou uma nova política de reorganização populacional dos índios e de suas relações com os colonizadores. Mas nem por isso os índios foram daí em diante trabalhadores livres e assalariados. Daí em diante foram adscritos à servidão não remunerada. A servidão dos índios na América não pode ser, por outro lado, simplesmente equiparada à servidão no feudalismo europeu, já que não incluía a suposta proteção de nenhum senhor feudal, nem sempre, nem necessariamente, a posse de uma porção de terra para cultivar, no lugar de salário. Sobretudo antes da Independência, a reprodução da força de trabalho do servo índio se fazia nas comunidades. Mas mesmo mais de cem anos depois da Independência, uma parte ampla da servidão indígena era obrigada a reproduzir sua força de trabalho por sua própria conta. E a outra forma de trabalho nãoassalariado, o não pago simplesmente, o trabalho escravo, foi adscrita, exclusivamente, à população trazida da futura África e chamada de negra. (QUIJANO, 2000: 207).

Desse ponto de vista, não se torna uma surpresa, muito menos uma casualidade histórica, que diversos Estados latinoamericanos tenham importado a força de trabalho imigrante europeia, branca, quando a era da escravidão necessariamente tinha que acabar (por pressão externa da Inglaterra ou em função da crise interna do escravismo). Desculpas racistas não faltariam para comprovar que o trabalho assalariado não era aptidão de negros e indígenas. A herança colonial não foi purgada, ou melhor, as determinações sociais coloniais não são exatamente uma herança - no sentido de que pertencem a uma época anterior. O elemento colonial, racial e negativo, baseado na relação de 
produção não-assalariada, portanto, inferior ao "padrão" estabelecido como o centro dessa sociabilidade, não é de modo algum pré-capitalista, ele é o resultado dessa forma social. A colonialidade é uma condição mesma da modernidade na periferia do capitalismo, pois suas relações objetivas e suas formas de subjetividade atravessam a constituição dessas sociedades, desses territórios e Estados. A manutenção de diferentes formas de inserção na economia capitalista e da discriminação ainda no interior do trabalho assalariado - quando este pressupõe a igualdade jurídica dos participantes do contrato de trabalho e igualdade formal daqueles que mantém a mesma relação - é a demonstração de que a colonização nunca propriamente foi abolida.

A classificação racial da população e a velha associação das novas identidades raciais dos colonizados com as formas de controle não pago, não assalariado, do trabalho, desenvolveu entre os europeus ou brancos a específica percepção de que o trabalho pago era privilégio dos brancos. A inferioridade racial dos colonizados implicava que não eram ESPAÇO E CULTURA, UERJ, RJ, N. 34, P.195-230, JUL./DEZ. DE 2013 http://www.e-publicacoes.uerj.br/index.php/espacoecultura/ dignos do pagamento de salário. Estavam naturalmente obrigados a trabalhar em benefício de seus amos. Não é muito difícil encontrar, ainda hoje, essa mesma atitude entre os terratenentes brancos de qualquer lugar do mundo. E o menor salário das raças inferiores pelo mesmo trabalho dos brancos, nos atuais centros capitalistas, não poderia ser, tampouco, explicado sem recorrer-se à classificação social racista da população do mundo. Em outras palavras, separadamente da colonialidade do poder capitalista mundial (QUIJANO, 2000: 207-208).

Essa contribuição original de Quijano preenche uma lacuna na crítica do capitalismo - o fato de que a teoria crítica das relações mercantis pressupõe uma igualdade abstrata nas entranhas da reprodução capitalista. O caráter abstrato do trabalho, a forma vazia e destrutiva do valor, a sua processualiade através da mercadoria e do capital não trazem, a principio, nenhuma marca que diferencie os agentes que colocam em movimento toda 
essa estrutura. $\mathrm{O}$ capital, assim, aparentemente não tem sexo ou raça.

Não há nada na relação social mesma do capital, ou nos mecanismos do mercado mundial, em geral no capitalismo, que implique a necessidade histórica da concentração, não só, mas sobretudo na Europa, do trabalho assalariado e depois, precisamente sobre essa base, da concentração da produção industrial capitalista durante mais de dois séculos. Teria sido perfeitamente factível, como o demonstra o fato de que assim de fato ocorreu após 1870, o controle europeu-ocidental do trabalho assalariado de qualquer setor da população mundial. E provavelmente mais benéfico para os europeus ocidentais. A explicação deve ser, pois, buscada em outra parte da história (QUIJANO, 2000: 207).

Como o capital não opera no vazio embora seu movimento destrutivo tenda a tragar toda a naturalidade, concretude e sociabilidade para o vazio de sua forma é preciso recorrer às condições históricas e geográficas em que sua lógica se desenvolve. A complexa história de configuração do mercado mundial, a invenção da América e sua fixação num sistema mundial têm como uma das faces a classificação e diferenciação de grupos que passam a ser inferiorizados no cenário mundial, circunscritos à formas específicas de produzir. Mas a mera contextualização não é suficiente, não se trata apenas de fazer uma correção metodológica da teoria com a empiria histórica. Pois a forma abstrata do valor e da mercadoria - o movimento logicamente "purificado" do capital - foi constituída sobre o reverso negativo racial e de gênero. Não basta uma correção sociologista da teoria crítica do capital, mas uma apreensão teórica de que o valor, a mercadoria e o capital não são neutros em termos raciais e sexuais, são na verdade constituídos pela afirmação da masculinidade branca, assim como o foi a forma do sujeito transcendental.

Através dessa formulação nova, uma teoria que possa fornecer "uma crítica radical do eurocentrismo" (QUIJANO, 2010: 64), não parte de um campo culturalista, muito menos de um campo econômico ou político, mas de uma crítica 
radical das formas como a modernidade/colonialidade constituiu cultura, economia e política etc. ${ }^{19}$ A acumulação e concentração de capital na Europa, que permitiu a esta "nova identidade geocultural" dar um salto histórico como centro do sistema mundial capitalista, tem suas raízes no mesmo processo de constituição de relações opositivas "centro-periferia", seja no plano econômico, seja no plano político ou cultural. Pois a concepção de uma superioridade frente às demais culturas é parte do histórico de exploração, pilhagem e destruição da América. $O$ nascimento da moderna sociedade capitalista na Europa é tanto um resultado da espoliação colonial quanto da descriminação e seleção estabelecida com a invenção do conceito de raça. ${ }^{20}$

A forma do capital, portanto, não é alheia aos critérios culturais em sua trajetória de desenvolvimento, daí que o desenvolvimento geográfico desigual esteja tão nítidamente relacionado às "identidades geoculturais". As formas do valor, da mercadoria e do capital estão histórica e logicamente vinculadas às determinações raciais e de gênero, mesmo que excluindoas como um elemento secundário, rebaixado, negativo de sua lógica - por isso o pensamento latino-americano que tenta refletir de modo minimamente crítico está sempre as voltas com essa formulação imprecisa de "produção capitalista de relações não-capitalistas". Assim como as categorias de negro ou índio não são externas à racionalidade ou à cultura europeia, mas o seu resultado mais preciso depois da destruição e amálgama de culturas tão diferentes, as relações de produção nãoassalariadas que foram adstritas a negros e índios não são "pré" ou "não-capitalistas", pois estão submetidas ao imperativo da produção de mercadorias e, portanto, à forma social geral do capital em sua circulação global.

Mesmo que negros e índios trabalhem como assalariados, isso não diminui em nada o peso dessa teoria, pois como Quijano já alertou, mesmo incorporados ao assalariamento, suas condições são quase sempre inferiores (precarizados, recebem salários menores etc.), assim como ocorre com as mulheres no mercado de trabalho em relação ao assalariado branco. A posição que esses grupos racial e sexualmente definidos ocupam na estrutura da relação modernidade/colonialidade não pode ser completamente identificada na empiria, pois é um "produto mental e social" que confina 
determinados indivíduos "não só à materialidade das relações sociais, mas à materialidade das próprias pessoas" (QUIJANO, 2005: 17). ${ }^{21}$

Também na relação de capital não há nenhum conteúdo, imediatamente, que implique em diferenças no relacionamento entre os gêneros. Mas a história da sociedade moderna tem sido marcada por uma profunda, original e violenta discriminação da mulher, que, como visto na expressão mais filosoficamente sistemática, em Kant, é tida como incapaz de alçar ao mundo elevado do pensamento racional. Do ponto de vista da modernidade, a mulher é o lado sensível, lascivo e natural que serve como mero objeto de contemplação, prazer ou de controle. Essa determinação da sensibilidade como qualidade intrínsecamente feminina não é ainda todo o processo de discriminação da mulher, pois, como a historiografia feminista tem demonstrado, na passagem do mundo medieval para o moderno, ela é confinada ao espaço doméstico, privado. Assim, a emergência da moderna relação de trabalho se completa com a cisão da mulher da esfera pública. Esta última, caracterizada pelo vínculo social utilitário, frieza mercantil e racionalidade empresarial, é despojada de todos os atributos que agora são identificados e projetados na mulher. Num movimento que terá seu auge com o Iluminismo, a visão do lar como o espaço do descanso, do amparo, enfim, da reprodução social (que se confunde com a função natural reprodutiva propriamente dita) é construída por uma domesticação da mulher:

(...) na segunda metade do século XVIII, criou-se uma imagem feminina que tornava a mulher novamente um ser da natureza. Essa imagem, no entanto, adquiriu uma nova coloração e uma nova qualidade, de vez que a mulher estava destinada "por natureza" a não ser mais que esposa, dona-de-casa e mãe (SCHOLZ, 1996: 24). ${ }^{22}$

Nesta relação entre a feminilidade e a natureza, a questão da moderna identidade do sujeito torna-se mais complexa, envolvendo tanto uma colonização externa quanto uma colonização interna à Europa. O processo de dissociação da mulher do trabalho, da atribuição de um estatuto inferior e doméstico é paralelo ao movimiento colonial de conquista da América. Mas não é isolado. A conquista do 
Novo Mundo é banhada por comparações e metáforas que associam a natureza selvagem, desconhecida e virgem ao caráter feminino. Por outro lado, a afirmação da identidade europeia no Velho Mundo passa pela desenfreada tentativa de controlar a sensibilidade, atributo cada vez mais "essencialmente" feminino. Como a subjetividade transcendental tem que ser trazida ao mundo através de uma contenção das paixões e dos desejos, a construção do sujeito moderno precisa apontar para fora de si a violência depuradora do rigoroso controle da sensibilidade, fazendo da perseguição das mulheres (suscetíveis às irracionais e malignas forças da natureza) parte do processo mesmo de colonização.

Esse processo de colonização interna da mulher se estendeu da queima das bruxas, que não por acaso coincidiu com o início da história colonial, até o século $\mathrm{XX}$, e em matéria de atrocidade não ficou nada atrás da guerra colonial externa. Não raro, ambas as formas andaram de braços dados. Em sua análise do sistema colonial francês, Frantz Fanon descreve, por exemplo, o caso de um oficial de polícia na Argélia que teve de ser conduzido a uma clínica psiquiátrica por ter começado a torturar seus próprios filhos e esposa (KURZ, 1998: 47).

Descoberta da América e caça às bruxas são dois eventos marcantes nos primórdios da sociedade moderna. Colonização externa nas novas terras descobertas e colonização interna da subjetividade europeia - esses dois movimentos não são autonômos, pelo contrário, são parte da gestação do mundo burguês. Através deles foram desenvolvidos simbolismos subjetivos e inclinações psicológicas que culminaram numa complexa representação da atividade sexual. A combinação das categorias da discriminação racial com a identificação rebaixada do gênero feminino marcou negativamente a forma do sujeito, criando uma multiplicidade de tratos sociais diferenciados que se acumulam na cultura burguesa. Assim, apenas para dar um exemplo, se a mulher é o inferior naturalizado frente ao homem, e o índio é o inculto pré-civilizado, a mulher índia é a combinação levada ao extremo dessas duas figurações, o ser natural lascivo e sem discriminação a ser utilizado exclusivamente 
para "colocar os desejos masculinos em execução", como escreveu um nobre italiano fazendo uso meramente sexual das nativas no primeiro século da colonização.

Neste particular, como em muitas descrições semelhantes nos séculos que se seguiram, a sexualidade dos índios exerceu uma complexa e poderosa atração sobre a psique europeia, desvendando a imagem de atividade sexual livre, desenfreada e natural, deflagrando dessa maneira uma combinação de reações que tinham muito a ver com o que era permitido e proibido, o liberado e o reprimido, o desejado e o temido, o humano e o animal. E se a satisfação dessas reações perturbadoras assumiam a forma de estupro e exploração, como parece que amiúde foi feito, isso, também, estava bem radicado na psique europeia, a atitude masculina em relação ao fraco, a civilizada em relação à natural: as mulheres da América eram parte tão integral do botim que cabia aos europeus conquistadores como quaisquer outros recursos com que se regalavam. $\mathrm{O}$ que se implantou dessa maneira nas décadas seguintes de contatos com os europeus não foi apenas uma futura população de mestizos, mas atitudes em relação a sexo e mulheres foram em tudo tão exploradoras e ditadas pela conveniencia quanto as em relação à natureza: MãeTerra e terra-mãe eram a única e a mesma coisa, ambas para serem usadas (SALE, 1992: 137). ${ }^{23}$

Não é de modo algum fortuito que um dos maiores biógrafos de Cristovão Colombo, o historiador norte-americano Samuel Eliot Morison, tenha tratado de modo sentimentalmente machista o feito do Almirante do Mar Oceano: "nunca mais poderão os mortais homens abrigar a esperança de sentir de novo o pasmo, o assombro, o encanto daqueles dias de outubro de 1492, quando o Novo Mundo cedeu graciosamente sua virgindade aos vitoriosos castelhanos". Edmundo O'Gorman (1995: 51), que repete essas 
palavras, não deixa de definir o evento histórico, desse ponto de vista, como "um estupro metafísico".

\section{Últimas notas}

O filósofo alemão Alfred SohnRethel (2008) estabeleceu em termos teóricos e históricos a relação entre a forma mercadoria e a forma da consciencia moderna, isto é, a "identidade secreta" entre mercadoria e o sujeito transcendental tal como exposto por Kant. Sua contribuição desenvolveu insights presentes na obra do jovem Lukács que, como poucos, devido a uma influência conjunta de Marx, Weber e Simmel, conseguiu demonstrar os vínculos entre a abstração do ato mercantil - a indiferença espacial e temporal dos processos econômicos - e a racionalidade pura que caracteriza a modernidade.

A partir de nossa reflexão anterior, fica claro que os vínculos entre a subjetividade transcendental e a seletividade cultural não decorrem de um "atraso", "desconhecimento" ou uma incorporação ainda não realizada de povos que são considerados, até então, como inferiores. Esse tipo de avaliação incorre na afirmação dessa subjetividade abstrata, como se ela pudesse abarcar culturas que foram, durante o nascimento dessa forma mesma, excluídos de sua constituição exatamente porque foram confinados ao lado negativo, rebaixado e objetivado. ${ }^{24}$

Disso decorre que, no caráter de alteridade das culturas constituídas pela colonialidade, não há nada que possa ser assumido como um elemento positivo a ser afirmado, já que essa alteridade é na verdade uma criação da modernidade, construída sobre a destruição das culturas originais. De outro lado, não se pode fazer dos pressupostos da modernidade enquanto tal uma plataforma de inclusão dos elementos negativos e dissociados, ou seja, como se fosse possível, através da "modernização", incluir na forma abstrata do sujeito exatamente aqueles conteúdos que foram desagregados e exteriorizados para sua formação. ${ }^{25}$ Como demonstra a experiência nacional dos Estados considerados "desenvolvidos", a democratização foi conseguida com o custo de homogeneização da sociedade sob hegemonia branca, que podia por isso criar uma mesma linha de relação através do assalariamento, diante da qual as demais raças e as mulheres assumiam posições sociais secundárias. ${ }^{26}$ Forçar a modernização 
em sociedades periféricas sem enfrentar os termos da colonialidade e da dissociação sexual seria simplesmente repetir o percurso da homogeneização social - não é por acaso que muitos projetos modernizadores ainda em curso na América Latina tenham como resultado imediato a destruição cultural ou física de "minorias" como indígenas, quilombolas, camponeses etc.

Não é possível confiar nos aspectos negativos conferidos pela colonialidade como uma racionalidade alternativa - pois esse universo não é de modo algum anterior ou totalmente externo à modernidade, mas sua contraface. Por outro lado, não dá mais para acreditar nos marcos pretensamente emancipatórios da modernidade esclarecida, pois para conceder liberdade e universalidade ao sujeito foi preciso reprimir e particularizar, discriminar aqueles que não cabem nesse invólucro abstrato. ${ }^{27}$

Entretanto, não se pode concluir pelo esquecimento ou indiferença frente às experiências culturais, às relações comunitárias, às práticas produtivas e

\section{Notas \\ 1 Professor Adjunto de Geografia do Departamento de Geociências da Universidade Federal Rural do Rio de Janeiro (UFRRJ). \\ 2 A expressão "invenção da América" foi originalmente cunhada pelo filósofo e historiador mexicano Edmundo O’Gorman (1995) para desconstruir o sentido de tratar a viagem de Colombo como uma descoberta, frente ao fato de que ele não foi o primeiro a encontrar o continente e sequer teve consciência desse feito. Ainda que os resultados sejam interessantes em revelar a}

técnicas dos povos que foram parcial ou totalmente destruídos na incorporação ao capitalismo. A questão é que todos esses traços, se eles ainda existem, estão hoje envolvidos numa forma de socialização que é movida pela mercadoria, pela discriminação racial e pela dissociação sexual. É esta forma enquanto tal que deve ser o objeto da crítica radical, mas isso não pode partir de uma particularidade interior positivada. A radical superação da socialização moderna deve partir exatamente de uma crítica imanente das contradições dessa forma, jogando seus antagonismos internos uns contra outros e não afirmando-os enquanto tais. Só assim as gerações passadas podem ser resgatadas naquilo que havia de socialmente emancipatório em suas formas. Pois "somente a humanidade redimida poderá apropriar-se totalmente do seu passado. Isso quer dizer: somente para a humanidade redimida o passado é citável, em cada um dos seus momentos" (BENJAMIN,1994: 223).

teleologia por trás dessa representação consolidada de descoberta, a abordagem de O'Gorman insiste numa hermenêutica que reduz todos os processos sociais à intencionalidade dos agentes.

3 "Com isto queremos deixar muito claro que a diacronia unilinear Grécia-Roma-Europa é uma invenção ideológica romântica e alemã de fins do século XVIII; é então um manejo conceitual posterior de 'modelo ariano', racista" (DUSSEL, 2005: 41).

4 "Em um sentido preciso, a história da modernidade começa no violento encontro entre Europa e América, no final do século XV, porque dali se segue, em ambos mundos, uma radical reconstituição da imagem do universo" (QUIJANO, 1988: 47).

5 "O ego moderno aparece em uma confrontação com o não-ego; os habitantes das novas terras descobertas não aparecem como ESPAÇO E CULTURA, UERJ, RJ, N. 34, P.195-230, JUL./DEZ. DE 2013 http://www.e-publicacoes.uerj.br/index.php/espacoecultura/ 
Outros, mas como o Mesmo a ser conquistado, colonizado, modernizado, civilizado, como 'matéria' do ego moderno. E é assim como os europeus (ou os ingleses em particular) se transformaram, como citávamos antes, nos 'missionários da civilização em todo o mundo', em especial com os 'povos bárbaros"”. (DUSSEL, 1992: 36).

6 "Bartolomé de Las Casas foi uma figura canônica daquela época. Nascido em 1484, veio à América em 1502 e foi o primeiro sacerdote ordenado aqui, em 1510. A princípio apoiou e tomou parte no sistema de encomienda, que compreendia o repartimiento dos ameríndios como mão de obra forçada para os espanhóis que administravam propriedades agrícolas, pecuárias ou mineiras. Mas em 1514 sofreu uma 'conversão' espiritual e renunciou à sua participação no sistema de encomienda, retornando a Espanha para se dedicar à denúncia das injustiças forjadas pelo sistema" (WALLERSTEIN, 2007: 17).

${ }^{7}$ Utilizamos aqui uma edição espanhola para as citações, pois a versão brasileira da obra de Las Casas (1991), apesar de muitas reedições, é uma tradução de uma antiga edição francesa. Além de vários problemas na tradução, há uma troca deliberada de "cristãos" para "espanhóis". Isso se explica pela chamada Leyenda Niegra, um conjunto de incriminações e denúncias levantadas contra a Espanha pelos demais países europeus empenhados na colonização da América, num objetivo de diferenciar sua ocupação frente à selvageria castelhana.

${ }^{8}$ E poderíamos dizer também para os asiáticos, mesmo na América (por exemplo, chineses e japoneses que trabalhavam em situação de semi-escravidão nos EUA, Brasil, Argentina etc.), assim como, em outros continentes, para a afirmação da identidade europeia, a violência se voltou contra judeus, muçulmanos, ciganos etc.

9 "Os homens brancos, munidos com seu cristianismo e seus ideais esclarecidos, não tinham esclarecimento algum acerca de si mesmo e, em sua superioridade bruta, não podiam chegar a qualquer compreensão que reconhecesse o valor próprio das culturas que lhe eram estranhas" (KURZ, 1998: 45-46).

${ }^{10}$ A conquista, assim, era tanto um processo de guerra contra os selvagens como contra a natureza, um violento arremesso da embrionária subjetividade racional contra a natureza do Novo Mundo. Kirkpatrick Sale (1992: 110-112) lembra, em vários momentos, que não é casual que Colombo tenha construído um "forte" como a primeira edificação do novo continente, assim como os ingleses em sua primeira colonização da América do Norte (1992: 258). Tratava-se do princípio mesmo da subjetividade nascente que precisa domar, subjugar e controlar a natureza: "A missão estava destinada a ser nada menos do que uma guerra entre homem e natureza, em um campo de batalha tão vasto $\mathrm{e}$, logo depois, tão pressionado que não tinha precedente $\mathrm{e}$ que só podia ter um resultado: a violência humana 'funciona' e a natureza pode ser subjugada, ainda que não derrotada, em curto prazo, e podem transcorrer gerações, mesmo séculos, antes que as conseqüências terríveis e irreversíveis de tal vitória se tornem evidentes. Era o tipo de vitória sobre a qual se baseava a premissa da América" (SALE, 1992: 277).

${ }^{11}$ Algumas dessas afirmações não deixam de ter algum fundamento real, embora interpretados de um ponto de vista em que a Europa começa a se colocar como referência para o mundo. Assim, a indisposição ao trabalho não é de modo algum desleixo, falta de ânimo ou fraqueza física, mas a simples incompreensão e rejeição de um processo social objetivo de suplício subjetivo para a produção - para as culturas que desconheciam o tempo abstrato, trabalhar horas a fio em atividades sem nenhum sentido que não o acúmulo de riquezas era tão absurdo quanto doentio. Sobre a afirmação de os índios serem "paupérrimos", seria necessário comparar os hábitos e o consumo europeu com a cultura de várias tribos "pré-colombianas" e atestar que do ponto de vista da satisfação pessoal, não apenas muitas sociedades indígenas apresentavam um nível de vida muito melhor como poderiam até ser consideradas tecnicamente superiores -- ver quanto isso, Kirkpatrick Sale (1992: 287-290 e 307), que, para demonstrar a superioridade das sociedades indígenas frente aos "civilizados", utiliza uma longa bibliografia de historiadores, ecologistas, antropólogos, incluindo aí os trabalhos menos conhecidos do geógrafo Carl Sauer.

${ }^{12}$ Las Casas (1986: 41) narra que um cacique, tendo luta contra os colonizadores, foi preso a um tronco e um franciscano "lhe deu algumas coisas de Deus e de nossa Fé", forçando um batizado algumas coisas de Deus e de nossa Fe, forçando um batizado céu. O cacique perguntou se os espanhóis também iam para o céu e, diante da resposta positiva do religioso, retrucou então que gostaria de ser encaminhado para o inferno, para não encontrá-los nunca mais.

${ }^{13}$ Para Hegel (1971: 116), analisar o africano é difícil porque para isso deve-se de imediato renunciar à categoria da universalidade. Assim, depois de algumas poucas palavras sobre seu fanatismo e idolatria, conclui que "com isso deixamos a África e não a mencionaremos mais. Pois não se trata de um continente histórico, não tem oferecido nenhum movimento ou evolução (...). O que por África propriamente entendemos é o carente de história e o que ainda não se abriu para algo superior, o que todavia se acha de todo confundido com o espírito natural e o que deveria ser mostrado como própria tão somente ao umbral da história universal" (1971: 122).

${ }_{14}$ Cada um olha o mundo ao seu redor e por isso se acha no centro dele: se em Hegel o império germânico é a finalidade mesma do caminho histórico do Espírito, para o historiador Lucien Febvre, embora desprovido de toda a pompa metafísica e escatologia do filósofo do Espírito, a Europa "nasceu (e bem nascida, de fato) da reunião e da lenta fusão de elementos nórdicos e de elementos mediterrâneos" (2004: 37-38), o que significa que a França é o país europeu por excelência, por situarse no centro desses dois mundos, participando tanto da vida do Mediterrâneo quanto de Flandres.

15 "Dizem-se europeus aqueles que têm a possibilidade de se tornar homens livres" (GOEHTE apud FERRO, 2004: 14)

${ }^{16}$ Com isto surge uma forma nova de discriminação, diferente das relações instituídas na antiguidade entre o civilizado e o bárbaro, pois a barbárie agora implica não apenas a incapacidade do uso da razão (ou da língua oficial), mas também uma ordem natural, racial diversa: "A mesma e velha preocupação grega discriminando uns homens de outros em função de uma suposta capacidade para o uso da razão ou do $\log _{0} s_{i}$ e a discriminação nova, que partirá agora da especificidade do que tem de natural o homem, e, portanto, do limitado que é para o homem o uso pleno da razão. Discriminação cultural e discriminação natural, mas sempre discriminação. $\mathrm{O}$ grego perfilou deste modo o tipo de homem por excelência, o capaz de conhecer e, ao conhecer, mandar. O moderno, o europeu-ocidental, forjará igualmente o tipo de homem por excelência: o capaz de dominar a natureza, pondo-a a seu serviço; mas incorporando dentro da natureza os homens que de um ou outro modo não a tivessem vencido" (ZEA, 2005: 64).

17 "No momento em que os ibéricos conquistaram, nomearam e colonizaram a América (cuja região norte ou América do Norte, colonizarão os britânicos um século mais tarde), encontraram um grande número de diferentes povos, cada um com sua própria história, linguagem, descobrimentos e produtos culturais, memória e identidade. São conhecidos os nomes dos mais desenvolvidos e sofisticados deles: astecas, maias, chimus, aimarás, incas, chibchas, etc. Trezentos anos mais tarde todos eles reduziam-se a uma única identidade: índios. Esta nova identidade era racial, colonial e negativa. Assim também sucedeu com os povos trazidos forçadamente da futura África como escravos: achantes, iorubás, zulus, congos, bacongos, etc. No lapso de trezentos anos, todos eles não eram outra coisa além de negros. (QUIJANO, 2000: 220-221).

${ }_{18}$ Muitos europeus brancos e pobres chegavam à América em condição de servidão devido a um contrato de prestação de "serviço" de duração variável durante a qual, para compensar os custos da viagem ou de manutenção, perdiam temporariamente sua liberdade. Embora não fosse o mesmo estatuto social do escravo, em alguns casos a situação de servidão podia ser pior, pois os proprietários de terra tinham menos interesse em manter suas condições de saúde, já que depois de um tempo não estavam mais sob sua responsabilidade, enquanto os negros eram um capital investido que devia ser utilizado por vários anos de trabalho. "... a experiência com a servidão branca era inestimável 
(...). Bristol, o centro do tráfico de trabalhadores, tornou-se um dos centros do tráfico de escravos. O capital acumulado de um financiava o outro. A servidão branca foi a base histórica em que se ergueu a escravidão negra" (WILLIAMS, 1975: 24).

19 Num texto antigo, publicado pela primeira vez em 1971, onde discutia cultura e dominação, ainda num linguajar um tanto quanto ortodoxo que ele mesmo reconheceu posteriormente como datado, Quijano (1980: 21) apontava para algo próximo disso: "... as relações que os grupos sociais guardam entre si com relação à cultura de sua sociedade, em cada momento, são fundamentalmente dependentes dos processos e configurações que têm lugar na estrutura básica de produção e de poder social e político acoplado, não é menos correto que isso ocorre somente através de uma engrenagem de instâncias e elementos de mediação, tanto mais indiretos e mais sutis - porque imprecisos e ardilosos - quanto mais elaborado e complexo, mais rico em matizes se apresenta um determinado núcleo de um universo cultural".

${ }^{20 " A}$ América Latina foi a primeira colônia da Europa moderna sem metáforas, já que historicamente foi a primeira 'periferia', antes da África ou do Ásia. A 'colonização' da vida cotidiana do índio, do escravo africano pouco depois, foi o primeiro processo 'europeu' de 'modernização', de civilização, de 'subsumir' (ou alienar) o Outro como 'o Mesmo', mas agora não mais como objeto de uma práxis guerreira, de violência pura - como no caso de Cortés contra os exércitos astecas, ou de Pizarro contra os incas - mas de uma práxis erótica, pedagógica, cultural, política, econômica, isto é, de domínio dos corpos do machismo sexual, da cultura, dos tipos de trabalho, de instituições criadas por uma nova burocracia política, etc., dominação do Outro" (DUSSEL, 1992: 49).

${ }^{21}$ Exemplo parecido é o fornecido por Roswitha Scholz (2007) em sua análise da atribuição da identidade de ciganos aos grupos Sinti e Roma na Europa. Assim como ocorreu com índios e negros, os ciganos também tiveram uma identificação na "materialidade das relações sociais" (para usarmos a expressão de Quijano). Eram associados a grupos de forasteiros, ociosos, pessoas livres vivendo de profissões como ferreiro, caldeireiro, malabaristas, músicos andarilhos etc., mesmo que em condições concretas e empíricas muitos deles não tivessem nenhum vínculo com essas atividades. Como padrão, com o Iluminismo nasce a visão do cigano como uma raça específica, inexistente até então — não deixando Kant de comparecer com suas impressões as mais racistas possíveis.

22 Em termos próximos ao de Quijano, mas com uma fundamentação teórica diversa, Roswitha Scholz (1996: 18) aponta os limites na compreensão tradicional de Marx: "a cisão sexualmente especificada não pode ser inferida diretamente da própria forma do valor. Ao invés disso, ela é numa certa medida a sombra lançada pelo valor, mas que não pode ser apreendida por intermédio do instrumental 'positivo' dos conceitos formulados por Marx. As cisões de que resultam a esfera feminina, o contexto de vida feminino e o âmbito de atividades imputado às mulheres (administração do lar, educação dos filhos, 'convívio social' etc.) são portanto elementos integrantes, por um lado, da socialização pelo valor, mas por outro, lhe são também exteriores. Como no entanto a cisão necessariamente faz parte do valor e com ele é posta, seria preciso criar um novo entendimento da socialização, capaz justamente de levar em conta o mecanismo patriarcal da cisão - não no sentido de um acréscimo externo, mas no de uma alteração qualitativa da própria teoria do valor, que seria assim também uma crítica do patriarcado".

${ }^{23}$ Se no caso da mulher índia há uma potencialização da atribuição colonial de inferioridade à sua posição social, na discriminação da mulher cigana ocorre o mesmo processo, onde os estereótipos são multiplicados: "Se já o 'cigano' masculino era e é encarado de modo suficientemente negativo, a 'cigana' é ainda pior pelo simples fato de não preencher o papel que lhe é atribuído num mundo masculino. Além disso, é ainda mais ladra do que o Sint, já de si um ladrão notório" (WIPPERMANN apud SCHOLZ, 2007).

${ }^{24}$ "Desde o século XVII, nos principais centros hegemônicos desse padrão mundial de poder (...) foi elaborado e formalizado um modo de produzir conhecimento que dava conta das necessidades cognitivas do capitalismo: a medição, a externalização (ou objetivação) do cognoscível em relação ao conhecedor, para o controle das relações dos indivíduos com a natureza e entre aquelas em relação a esta, em especial a propriedade dos recursos de produção. Dentro dessa mesma orientação foram também, já formalmente, naturalizadas as experiências, identidades e relações históricas da colonialidade e da distribuição geocultural do poder capitalista mundial. Esse modo de conhecimento foi, pelo seu caráter e pela sua origem, eurocêntrico. Denominado racional, foi imposto e admitido no conjunto do mundo capitalista como a única racionalidade válida e como emblema da modernidade" (QUIJANO, 2000a: 343). Sobre isso, ver também a discussão de Quijano (1992: 442) de como a relação entre o moderno e o colonial não pôde se constituir como uma relação intersubjetiva porque para o europeu as demais culturais "somente podem ser "objetos".

${ }^{25}$ Em que pese todas as reflexões ricas, a obra de Leopoldo Zea (2005) é um exemplo exato desse princípio, principalmente a sua afirmação filosófica de um projeto assuntivo, isto é, sua intenção de construir uma filosofia autêntica da América Latina. Num registro teórico diferente, Enrique Dussel (1990: 268) clama por uma "libertação nacional e popular" utilizando-se da crítica madura de Marx à filosofia da história para também estabelecer afirmativamente uma filosofia latino-americana.

${ }^{26}$ Sobre isso, ver a significativa diferença de abordagem de Quijano (2000b) em relação aos tradicionais aspectos da teoria da dependência.

As utopias modernas foram, contraditoriamente, alimentadas pela imagem da América e isso corrobora essa afirmação da identidade europeia através da conquista da América. Contudo, no momento em que realizou importante reflexão sobre isso, Quijano (1988: 33) ainda confiava nas "promessas libertadoras da modernidade". Nessa obra há uma estranha oposição entre a "racionalidade instrumental anglo-escocesa" e uma "razão histórica francesacontinental", que serve apenas salvar os momentos "humanistas" do pensamento moderno.

\section{Referências \\ Bibliográficas}

BENJAMIN, Walter. Sobre o conceito da História. In: Obras Escolhidas - Magia e Técnica, Arte e Política. São Paulo: Brasiliense, 1994, pp. 222-232.

DUSSEL, Enrique. El último Marx (1863-1882) y la liberación latinoamericana. Cidade do México: Siglo XXI, 1990. 1492: El encubrimiento del Outro: hacia el origen del "mito de la Modernidad". La Paz: Plural Editores, 1995. . Europa, modernidad y eurocentrismo. In: Colonialidad del Saber y Eurocentrismo. LANDER, Edgardo (Ed.). Buenos Aires: Unesco/Clascos, 2000, pp. 41-53.

FEBVRE, Lucien. A Europa: Gênese de Uma Civilização. Bauru Edusc, 2004. FERGUSON, Niall. Império - como os britânicos fizeram o mundo moderno. São Paulo: Editora Planeta, 2010.

FERRO, Marc. Prefácio. In: FEBVRE, Lucien. A Europa: Gênese de Uma Civilização. Bauru: Edusc, 2004, pp. 9-15.

HEGEL, Georg W. F. Filosofía de la historia. Barcelona: Ediciones Zeus, 1971.

Introdução à Filosofia da História (Os Pensadores). São Paulo: Abril Cultura, 1974.

Princípios da Filosofia do Direito. São Paulo: Martins Fontes, 1997. KANT, Immanuel. Lo bello y lo sublime: ensayo de estética y moral. Disponível em: http://www.cervantesvirtual.com/obra-visor/lo-bello-ylo-sublime-ensayo-de-estetica-y-moral0/html/fefdabe2-82b1-11df-acc7-002185ce6064_2.htm. Acesso em: nov. 2013. 
KURZ, Robert. Os últimos combates. Petrópolis: Vozes, 1998.

LAS CASAS, Bartolomé. Brevíssima Relación de la Destrucción de Las Indias. Barcelona: Ediciones Orbis, 1986 (versão eletrônica).

O Paraíso Destruído: Brevíssima Relação da Destruição das Índias. Porto Alegre: L\&PM, 1991.

MONTAIGNE, Michel de. Ensaios (livro III). Disponível em: http://pt.scribd.com/doc/110951205/MontaigneEnsaios-Livro-III. Acesso em O'GORMAN, Edmundo. La Invención de América: investigación acerca de la estructura histórica del nuevo mundo y del sentido de su devenir. Cidade do México: Fondo de Cultura Económica, 1995.

QUIJANO, Aníbal. Dominacion y cultura: lo cholo y el conflicto cultural em el Perú. Lima: Mosca Azul Editores, 1980. . Modernidade, identidad y utopia em América Latina. Lima: Sociedad y Politica Ediciones, 1988

Colonialidad y Modernidad/Racionalidad. In: Heraclio Bonilla (comp.): Los Conquistados. 1492 y la población indígena de las Américas. Bogotá: FLACSO-Tercer Mundo, 1992, pp.438-447.

"iQué tal raza!" In: Calderón, Edith Benado (org.). Familia y cambio social. Lima: CECOSAM, 1999, pp. 186-202.

Colonialidad del poder, eurocentrismo y América Latina. In: Colonialidad del Saber y Eurocentrismo. LANDER, Edgardo (Ed.). Buenos Aires: Unesco/Clascos, 2000, pp. 201-246.

Colonialidad del poder y classificación social. In: Journal of World-Systems Research, vol. XI, no. 2, 2000a, pp. 342-386.
El fantasma del desarollo em América Latina. In: Revista Venezolana de Economía y Ciencias Sociales, vol. 6, no. 2, maio-ago. 2000b, pp. 73-90.

Dom Quixote e os moinhos de vento na América Latina. In: Estudos Avançados, no. 19 (55), 2005, pp. 931 .

"América Latina: hacia um nuevo sentido histórico". In: León, Irene (coord.). Sumak Kawsay/Buen Vivir y cambios civilizatórios. Quito:

SALE, Kirkpatrick. A Conquista do Paraíso: Cristovão Colombo e seu legado. Rio de Janeiro: Jorge Zahar, 1991.

SCHOLZ, Roswitha. O valor é homem - teses sobre a socialização pelo valor e a relação entre os sexos. In: Novos Estudos CEBRAP, no. 45, junho de 1996, pp. 15 36.

. Homo sacer e 'os 'ciganos': o anticiganismo - reflexões sobre uma variação essencial e por isso 'esquecida' do racismo moderno. Disponível em: http://obeco.planetaclix.pt/roswitha-scholz7.htm. Acesso em dez. 2007.

SOHN-RETHEL, Alfred. Trabalho espiritual e corporal: para a epistemologia da história ocidental. Disponível em: http://adorno.planetaclix.pt/sohn-rethel.htm. Acesso em: dez. 2008.

WALLERSTEIN, Immanuel. Universalismo europeo: o discurso do poder. Cidade do México: Siglo XXI, 2007.

WEDEL, Karl-Heinz. A descida do eu aos infernos: da forma da morte da vontade destituída de sentido em Kant. Disponível http://grupokrisis2003.blogspot.com.br/2009/06/karlheinz-wedel.html Acesso em: dez. 2010.

WILLIAMS, Eric. Capitalismo e Escravidão. Rio de Janeiro: Ed. Americana, 1975.

ABSTRACT: THE AIM OF THIS TEXT IS TO RELATE THE DISCOVERY AND CONQUEST OF THE AMERICAN CONTINENT NOT ONLY WITH THE BUILDING OF THE EUROPEAN HISTORICAL AND GEOGRAPHICAL IDENTITY, BUT ALSO WITH THE STRUCTURE OF MODERN SUBJECTIVITY. AS PART OF THIS PROCESS, THE ASSUMPTIONS OF EUROPEAN SUPERIORITY ARE EMPHASIZED IN THEIR PARTICULAR RACIAL, GENDER, AND ENDOWED WITH A RATIONALITY THAT REVEAL THE EUROCENTRISM CONSTITUTED OF THE RELATIONSHIP BETWEEN MODERNITY AND COLONIALITY. 
KEYWORDS: MODERNITY, COLONIALITY, IDENTITY, RACISM, SUBJECTIVITY

LA COLONIALIDAD Y FORMA DE SUBJETIVIDAD MODERNA: LA VIOLENCIA DE LA IDENTIDAD CULTURAL EN AMÉRICA LATINA

RESUMEN: El OBJETIVO DE ESTE TEXTO ES RELACIONAR EL DESCUBRIMIENTO Y CONQUISTA DEL CONTINENTE AMERICANO, NO SÓLO CON LA CONSTRUCCIÓN DE LA IDENTIDAD HISTÓRICA Y GEOGRÁFICA EUROPEA, SINO TAMBIÉN CON LA ESTRUCTURA DE LA SUBJETIVIDAD MODERNA. COMO PARTE DE ESTE PROCESO, LOS SUPUESTOS DE LA SUPERIORIDAD EUROPEA SE DESTACAN EN SU CARACTERISTICA RACIAL, DE GÉNERO, Y DOTADOS DE UNA RACIONALIDAD QUE REVELAN EL EUROCENTRISMO CONSTITUIDO DE LA RELACIÓN ENTRE LA MODERNIDAD Y COLONIALIDAD.

PALABRAS CLAVE: MODERNIDAD, COLONIALIDAD, IDENTIDAD, RACISMO, SUBJEIVIDAD 